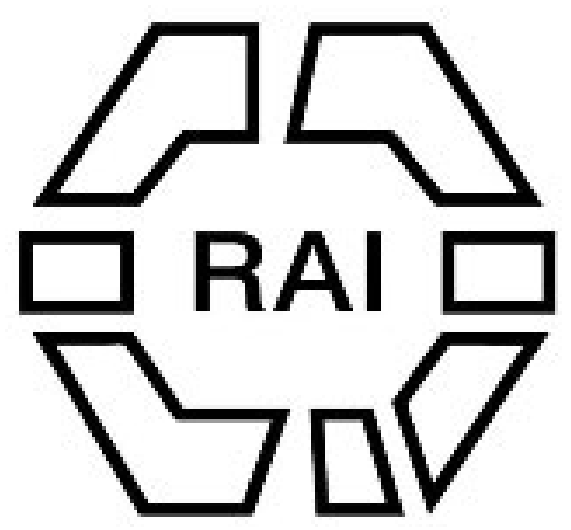

On the Races of the West Indies.

Author(s): E. F. Im Thurn

Source: The Journal of the Anthropological Institute of Great Britain and Ireland, Vol. 16 (1887), pp. 190-196

Published by: Royal Anthropological Institute of Great Britain and Ireland

Stable URL: http://www.jstor.org/stable/2841804

Accessed: 15/06/2014 00:01

Your use of the JSTOR archive indicates your acceptance of the Terms \& Conditions of Use, available at http://www.jstor.org/page/info/about/policies/terms.jsp

JSTOR is a not-for-profit service that helps scholars, researchers, and students discover, use, and build upon a wide range of content in a trusted digital archive. We use information technology and tools to increase productivity and facilitate new forms of scholarship. For more information about JSTOR, please contact support@jstor.org. 
Since there are not sufficient exhibits to serve as a text for discussions about the Red Indians, our hour must be assigned to other races, who fall under the same title of Native Races in the British Possessions of America, and who are well represented in this Exhibition. But before beginning upon these I shall be happy to give a very few minutes to any gentleman who may be disposed to make brief remarks about these temporarily overlooked red Canadian natives. The objects on the table come from British Columbia; they are taken from the exhibits under the charge of Dr. Selwyn, who, unless I am mistaken, regrets the inadequacy of the exhibits relating to Red Indians as much as $\mathrm{I}$ do. $\mathrm{He}$ is unfortunately unable to be present.

\section{On the RACES of the WEST InDIES.}

\section{By E. F. Im Thurn, Esq.}

THE information at present available as to the red races of the West Indian Islands and of the immediately adjoining mainland is but fragmentary. Certain points have been somewhat minutely investigated, many others have as yet hardly been examined. In trying to piece together from such unsatisfactory data as these an outline of the probable facts concerning the history of these races, I seem to feel myself somewhat in the position of one who lays down a map of a country of which only certain isolated spots are known, of which vast tracts have never been visited. Just as this map-maker, after he has placed on his paper the known points has to draw from conjecture the surrounding country, so I must, on this occasion, suggest the probable connection of the few ascertained facts which I have to tell. Probable and possible are words that I am forced to use frequently but with carefully considered significance.

At the time of their discovery the West Indian Islands were found to be inhabited by red-skinned people of altogether peculiar character. They were the first examples seen by Europeans of the remarkable race of men which is peculiar to the Western Hemisphere. The accounts of the first interviews of Columbus and his immediate followers with these new people in this newly discovered world, are of the very greatest historical -or to use a wider word, anthropological-interest. They raise, surely, in the imagination of any reader, a wonderful picture-a picture of the first meeting of the man of white skin, the product of the social development which had been in rapid progress for long ages in the eastern world, with the man of red skin, the product of the social development which during those same ages, 
with far less rapid progress, had existed in the western world. The men of the east thus for the first time visited and saw the men of the west. The mind of the zealous anthropologist is almost appalled at the greatness and splendour of the opportunity which those men of the east then had-and lost.

But those portions of the American race which were thus first discovered in the West Indian Islands, were extinguished with remarkable rapidity. The larger number were enslaved, and with a slavery so cruel that they soon perished. Others lingered on, carrying on a more or less desultory warfare with the white colonists, who flocked from the east into the islands of the west. The history of what was, I believe, the latest instance of active fighting between West Indian colonists and West Indian red men, that in St. Vincent, will be told you far better by Mr. Hawtayne, who has kindly consented to read this paper for me, than I could tell it. The general result of slavery and war has been the almost complete extermination of the West Indian red man. A very few pure-blooded representatives of the race survive in two or three of the islands; and it would be a very good thing if these survivors were carefully examined, and if their number and condition were recorded. A few other people with red blood-so-called black Caribs-are to be found in St. Vincent, and probably in some other of the islands. These are hybrids between the genuine red West Indian and the imported black African, and are of very curious interest. Mr. Hawtayne, with much greater experience, can give you much better information of these people than can I. For my part, I may, however, tell you that these island hybrids correspond exactly with the hybrids, not very rare in certain parts of Guiana and of Brazil, between red men and negroes. In Guiana they are called Cobungroos. Physically, at any rate, the mixture is a most successful one. Finer men, or better suited for life in the parts where their lot is cast, than the Cobungroos of the edge of the forest country of Guiana, it would be hard to imagine. I should like to place on record that it was to one of these people, a young fellow named Gabriel, that I very largely owe my success in ascending Roraima.

The few surviving traces of these extinct island races are naturally of the very greatest anthropological importance. These are chiefly of two kinds, one of which is represented by the few surviving traces of the languages of these races, that is of a few brief vocabularies and of a large number of place-names; the other being represented by the products of the simple arts of these races, the implements of stone, shell, clay and wood.

Concerning the traces of languages, all that I can here do is to remind you that, as regards the Arawak language of the 
islands, Dr. Brinton has admirably summarised the little existing information in a paper contributed to the "Transactions of the American Philosophical Society" (since reprinted in pamphlet form), and that a Carib grammar of the 17th century, by a French priest then resident in Dominica(?) exists, and has of late years been reprinted by M. Adam in Paris. I may add that Mr. Ling Roth, who will, I trust, be present at the reading of this paper, has made considerable study of the language of the island Arawaks, and will give you, I hope, more information on this subject than I can. As regards the place-names, I have been for some years collecting them, and I hope soon to publish the information which they throw on the extinct people who originally gave them. To close my few remarks on the subject of language, I may also tell you that I possess the M.S. of an Arawak grammar written by the late Rev. W. H. Brett, a man of great learning on that subject; and that I also possess, through the extreme kindness of my American friends, a M.S. German-Arawak dictionary, compiled during the last century by a Moravian missionary. Both of these latter linguistic materials refer, it is true, to the Arawaks of the mainland, not to those of the islands, but they cannot fail when published, as I hope they will be in due time, to throw much light on the insular languages.

More enduring than the linguistic traces are the implements of stone, shell, clay and wood. Various collections of these, some of considerable extent, have been made, and afford much, at present hardly used, material for study. Foremost should, I think, be mentioned the Latimer collection, now incorporated in the United States Museum at Washington. This collection was brought together by an Englishman, but an American subject, George Latimer, who was for a long period a merchant and American Consul in Porto Rico. It was bequeathed by him to the American nation. It has been admirably described by Professor Otis T. Mason in the "Proceedings of the Smithsonian Institute." Its fault, a fault, alas, common to almost every such collection, is that it carries with it no record of the special place and circumstances of the discovery of each stone. Next, I suppose, in interest among the public collections must rank that portion of the Christy collection, in the British Museum, which consists of the stone implements from the West Indies. While it contains some very interesting examples, it is far from sufficiently representative, and I think I may safely plead with those Englishmen who are possessors of West Indian stone implements to add them to our national collection, which has great need of such specimens. Another public collection, the Blackmore Museum at Salisbury, contains some interesting West Indian examples, the best of which have been described in Mr. 
E. T. Stevens's “Flint Chips." Turning now to private collections, among the more interesting of these may be mentioned that of Sir Thomas Graham Briggs, of Barbados. A selection of the best examples of this collection has been kindly lent to me by its owner, and many of them have been figured in my "Notes on West Indian Stone Implements," in "Timehri," our Guiana scientific journal. Another portion of this collection fills one of the large cases in the West Indian Court of the Exhibition. Mr. E. A. Atkinson, now of Trinidad, possesses a small but very interesting collection, some examples of which he has been good enough to give me, others he has lent me. These too have been figured in "Timehri." Dr. H. A. Alford Nichols, of Dominica, has also brought together a considerable number of examples, the whole of which will be found in the Exhibition. My own collection, which, at least in point of numbers, exceeds any of these private collections, is unfortunately in Guiana, whence special circumstances prevented my bringing it, as I should like to have done, to the Exhibition. Various other small but very interesting collections, are, however, there shown, by M. Th. Rousselot, Esq.

Of these the first should be especially examined.

Time forbids my describing in any very great detail the material thus nominally brought together. I may, however, briefly allude to some of the more interesting features of the collection thus laid before your imagination.

I think there is now hardly any part of the world from which stone implements have not been procured, and it is a platitude to remark that of these certain types occur with wonderful similarity, almost everywhere. Commonest of these is what I have elsewhere described as the "petalloid" type. Its chief representive is shaped like the long narrow petal of a flower, e.g., of a ranunculus. Round this representative of the type may be grouped many more or less slight variations of form. But taking the type as a whole it may be said to be spread universally over the globe. The explanation of this of course is, that implements of this shape are, as axes, adzes, and chisels, tools for the simplest, earliest, and most necessary purposes, and that their form is consequently that naturally first devised by one of the earliest efforts of imagination by all primitive folk, whether isolated or not, in all parts of the world. It is as common in the West Indies as elsewhere, and many examples of it will be found in the show cases of the Exhibition. Some of them will be found to be polished and finished to a very high degree. Especially may attention be called to one extraordinarily highly polished and beautiful example from Antigua, the property of Bishop Branch. 
But in the matter of stone implements, as in other matters, if the earliest devised forms of the most primitive folk are the same, or very nearly the same, in all parts of the world, the next, and in increasing degree, all further devised forms are apt to be different in different parts of the world. That is, each folk, starting from a very similar because very simple form, develops for itself, according to its own peculiar surrounding circumstances, higher forms specially suited to its own circumstances. Thus just as it is true that implements of the simplest kind from different parts of the world are of identical form, so it is true that implements of more elaborate kind are, more or less, of distinct and peculiar form in each different part of the world. The type of implement peculiar to the West Indies is very peculiar, I believe I may say unique, and indicates so high an artistic advance that it is a matter of extreme regret that more of the cireumstances which led to this advance are not known. I may add in treating of these artistic forms that the materials employed were of various kinds, including not only stone, but also clay, wood, and, though this does not lend itself to much artistic elaboration, shell.

The peculiarity of this West Indian art may not unfairly be described as the application of an unusual elaborateness of sculpture. This was probably first used as a mere means of adorning implements of practical utility. This stage is well illustrated by many examples in the exhibition, of which the following may be especially noted :-

1. One in left hand large case, winged and grooved, thusNowhere else, I believe, but in the West Indies, or possibly on the immediately adjoining mainland, would such a form be found. It is a specially good example of many forms more or less slightly diverging from it, and the whole group thus formed should, I think, be regarded as the most remarkable feature in the history of the West Indian stone age.

2. A large example, in the same case, from the Grenada Public Library, should also be especially noted for the sake of comparison.

3. A form approaching that already mentioned, but perforated, should also be noted. They are fairly common in the West Indies, and there are one or two examples, though no very fine one, in the Exhibition. Its shape is here represented-

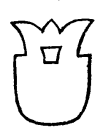

That these examples thus described were not individual eccentricities, but represent forms once commonly made, is, I think, shown by the fact that they occur not only in considerable numbers, but of all sizes, from barely an inch long to twelve inches long and more. 
But if, as has been suggested, this sculpture was first applied as mere ornament to practical implements, it seems to have been used, probably later, for the adornment of stones, or of other material, for merely ornamental, or perhaps symbolic, purposes. It seems as though the West Indian sculptor ran riot with his art and often wrought an implement, frequently at the cost of what must have been considerable labour, into curious forms apparently impossible of practical use. Before describing some of these forms, which have been described somewhat meaninglessly as " banner-stones "-and the term, in default of a better, is useful-I will just point out two facts bearing on this special matter. The first is that still at the present day the red men of the mainland are very apt when they see a piece of wood of curious natural form-suggesting, say, some animal-to take that wood and, with more or less artistic touches, to complete its resemblance to that animal. It is perhaps worth notice as a curious survival of, or reversion to, this practice that there is at Stratford-on-Avon, a man who has a museum-a "phusoglyptic museum" he calls it-of such natural pieces of wood which, merely by a few touches of art, he has transferred to the shapes of various animals. The second fact to which I propose to refer is that there is another possible explanation than that given above of the historical relation of the West Indian banner-stones to the West Indian practical implements ornamented by sculpture; and this is that the red man first applied sculpture merely by way of amusement to certain stones the natural shape of which suggested some peculiar form to his mind, and that having thus developed his artistic skill, he then only in the second place applied this artistic sculpture to the ornamentation of the practical implements of simple form which he was already in the habit of using. The difference between the two possible theories is merely this: the one suggests that sculpture was first applied to the development, in an artistic line, of practical implements, and then was allowed to run riot in the production of "banner-stones"; the other that banner-stones were first made as an amusement, and the art thus gained was combined with that employed in the production of practical implements.

Leaving the choice between these two theories open, I will now turn to the description of one or two examples of bannerstones.

1. The very essential idea of a "banner-stone" being that it should be of no (unless of symbolic) use, I may allude first to one which fulfills these conditions most perfectly. I have placed a photograph of the stone in one of the cases of implements from British Honduras. Its form is so eccentric and 
meaningless as to defy description, and I can only advise those who are interested in such matters to examine the photograph. The original implement is part of the Atkinson collection, but is now in my care. It must have been manufactured at the cost of a very considerable amount of labour. It has been fully described and figured in "Timehri."

\section{Remarks on the CARIBS.}

\section{$B y$ G. H. Hawtayne, Esq., C.M.G.}

There is not much to be said by me in addition to what is contained in Mr. Im Thurn's paper. In the Island of St. Vincent there were and still are, two kinds of Caribs, one the yellow or red man whom the paper just read mentions, and the other a hybrid race a mixture of yellow Caribs with some African slaves who about 1632 were wrecked on the shores of Bequia, an island close to St. Vincent. Quarrels and wars arose between the two tribes, and eventually the black Caribs settled on the leeward or northwestern coast, and the yellow on the opposite side of the island. They were formidable enemies to the British, whose army of 5,000 men, led by Sir Ralph Abercrombie and other distingujshed generals, had a difficult task to subdue their savage opponents, aided by officers and men of the French Republican army. One of these black Caribs, Chatoyer, was the leader of the rebels. There is an engraving in the West Indian Court from a picture painted for Sir William Young from life, representing this savage chief and his five wives. Their features show their partly African descent, and the women are there represented carrying their loads in sunanas, which are baskets woven from a species of Maranta, strung on the back and supported by a band across the forehead, just as the figure of the Acawoi woman in the British Guiana Court is carrying hers. These black Caribs, when African slaves were imported to till the fields of the European planters, became alarmed lest their descendants might be mistaken for those of the servile race, and compelled to labour, and so the practice was instituted of compressing the foreheads of newborn children so as to distinguish them from pure Africans. This custom, however, has long died out, but skulls are to be found with receding foreheads thus caused. The Black Caribs inhabit a small tract of land near the foot of the Souffrière Mountain granted to them in 1805. They are excellent boatmen and live by fishing. They also make a few baskets of neat workmanship. In 1879 the black and yellow Caribs were said to number 431, but of these several were not of pure blood. In 1735 they were estimated at 10,000, but many were killed in the war of 1795-6, and upward of 5,000 were transported to Ruatan in the Bay of Honduras. The prisoners of war were, however, first sent to a small island near St. Vincent, called Balliceaux, where 